\title{
Implementation of Complete Systematic Land Registration Program (PTSL) Based on Government Regulation No. 24 of 1997 on Land Registration in the Subang District
}

\author{
Hani Handayani ${ }^{1}$, Rizky Adiyanzah Wicaksono ${ }^{2}$ and Amin \\ Purnawan $^{3}$
}

Abstract. The purpose of this study are to: 1 ) to investigate the implementation of Complete Systematic Land Registration Program based on Government Regulation No. 24 of 1997 on Land Registration in Subang district. 2) To know the constraints and solutions implementation of Complete Systematic Land Registration Program based on Government Regulation No. 24 of 1997 on Land Registration in Subang district.

In this study the authors use research methods socio-juridical / empirical / nondoctrina/ where qualitative approach is a way of analysis of the results of research that produces descriptive data analysis, the data stated by the respondent in writing or orally as well as the real behavior, researched and studied as something related intact on Government Regulation No. 24 of 1997 on Land Registration in Subang district.

Based on the results of data analysis concluded that: 1) Implementation of Complete Systematic Land Registration Program based on Government Regulation No. 24 of 1997 on Land Registration in Subang district. Implementation of Complete Systematic Land Registration program in the Subang district earring positive influence on the creation of orderly land, particularly against the rule of law and orderly administration of land, which is indicated by the number of parcels of land have been able certified in the land registration process. This will have an impact on the decrease in the number of land disputes, because residents have proof of land ownership (certificate) and the presence of land records are complete.

Keywords: Complete Systematic Land Registration Program, Government Regulation No. 24 of 1997 on Land Registration.

\section{Introduction}

Land is a gift of God the Almighty for the prosperity of the Indonesian people, so the Indonesian nation relationship with the land is eternal. Land is the one resource that is essential to the survival of the human race, the human relationship with the land is not just a place to live, but more of that land is a place where people live and thrive, the soil becomes the source for all the interests of human life.

To realize the state policy regarding the structuring and management of natural resources, as stipulated in Article 33 paragraph (3) of the Constitution of the Republic of Indonesia Of 1945, which says: "The earth and water and natural resources contained therein controlled by the state and used as possible for the prosperity of the people", the state set national guidelines in the area of land which is one of the many

\footnotetext{
${ }^{1}$ Students of Master of Notarial Law, Faculty of Law, Universitas Islam Sultan Agung email: hannyhoney509@gmail.com

2 Students of Master of Law, Faculty of Law, Universitas Islam Sultan Agung email rizkywicaksono18@gmail.com

${ }^{3}$ Lecturer of Faculty of Law UNISSULA Semarang
} 
important elements of the natural resources that exist. Therefore, on the 24th of September 1960 the enactment of Act No. 5 of 1960 on Basic Regulation of Agrarian. ${ }^{4}$ Considering that the land registration which operate by Act No. 5 of 1960 on Basic Regulation of Agrarian assigned to the government, is a means of ensuring legal certainty which meant the government passed the Indonesian Government Regulation No. 24 of 1997 on Land Registration aims to guaranteeing the rights and legal certainty of land, agrarian key legislation has outlined the necessity to carry out land registration throughout Indonesia. ${ }^{5}$

Article 1 paragraph 1 Indonesian Government Regulation No. 24 of 1997 on Land Registration are: The land registry is a series of activities carried out by the Government continuously, continously and regularly, includes collecting, management, accounting, and presentation as well as the maintenance of physical data and juridical, in the form of maps and lists, on plots and apartment units, including the granting of rights letter of receipt for parcels of existing rights and ownership of the apartment units as well as certain rights which encumber".

With the convening of land registration, then the parties concerned can easily know the status or legal position than certain ground faces, location, area and boundaries, who have and load what is on it. $^{6}$

Subang District Land Office is the official sanctioning body of land especially regarding complete systematic land registration in the jurisdiction of Subang district. In the implementation of government programs for land registration systematically complete've done in Subang, there are still constraints in implementing the program in terms of the rules of government regulations contained in Article 26 paragraph (1) the Indonesian Government Regulation No. 24 of 1997 on Land Registration announced basically is data physical and juridical data which will be the basis of registration of land parcels in question to facilitate its implementation, the systematic land registration announcements should not be done all at once on all parcels of land in the area that has been set, but can be implemented in phases.

The next issue, how the binding strength Regulation of the Minister of Agrarian and Spatial Planning / Head of National Land Agency No. 6 of 2018 refers to Article 8, paragraph (2) of the Act No. 12 of 2011 states: "Laws and regulations as referred to in paragraph (1) recognized and have binding legal force throughout ordered by legislation that is higher or formed under the authority".

There are two requirements for a ministerial regulation has binding force as the legislation, which was ordered by the legislation that is higher or established pursuant to the authority. When referring to Article 19 of the Basic Agrarian Law, activities of Complete Systematic Land Registration is an order of Article 19 of the Basic Agrarian Law as a legal source ministerial regulations. This means that the lower regulation must not contradict higher laws.

Based on the foregoing, the authors were interested in examining in depth the results of which will be poured into the form of a thesis entitled: "The implementation of Complete Systematic Land Registration Program Based on Government Regulation No. 24 of 1997 on Land Registration in Subang District".

\section{Research methods}

\footnotetext{
${ }^{4}$ Elucidation of Article 33 paragraph 3 of the Constitution of the republic of Indonesia Of 1945.

${ }^{5}$ See preamble Indonesian Government Regulation No. 24 of 1997 on Land Registration.

${ }^{6}$ Effendi Perangin Hukum Agraria Indonesia CV. Rajawali. Jakarta 1991 p. 95.
} 
The method approach used in this study is primarily descriptive analytical approach. Descriptive analysis is research that describes an analysis of the existing findings. ${ }^{7}$ Descriptive analysis approach in this study, is the regulatory approach in terms of legislation and legal norms in accordance with the existing problems.

\section{Results and Discussion}

\subsection{Implementation of Complete Systematic Land Registration Program Based On} Government Regulation No. 24 of 1997 on Land Registration in Subang district.

A policy program directed against a public interest, the interest of which is affected or influenced by a policy concerning the extent to which the interests of the target audience or the target groups included in the contents of the policy. Inters affected with regard to a variety of interests that influence policy implementation. This indicator argued that a policy in the implementation of the program certainly involves a lot of interest, and the extent to which these interests had an impact on implementation.

At the bottom of the owner of plots require a legal protection to be strong evidence and legal basis for owners of land afar obtain legal certainty by Article 19 of Act No. 5 of 1960 on Basic Regulation of Agrarian inside explains that: "In order to ensure legal certainty by the Government held land registration throughout the territory of the Republic of Indonesia in accordance with the provisions stipulated in Government Regulation. The registration includes: Measurement, mapping and soil bookkeeping; Registration of rights to land and transfer of these rights; Award letters proof of rights, which serves as a strong evidentiary tool. "

In the program of land registration systematically complete set forth in Regulation of the Minister of Agrarian and Spatial Planning / Head of National Land Agency of the Republic of Indonesia Number 12 Of 2017 on the Acceleration of the Complete Systematic Land Registration loaded that the public owners of land parcels secured needs legal certainty on parcels of land which they are entitled through the issuance of a certificate of land will be owned by the community.

Policy program also stipulates collection of all objects land registration throughout the territory of the Republic of Indonesia in the development of the rural areas / villages or any other name that is level with it, which involves the collection and determination of the truth of physical data and juridical data regarding one or more objects of registration of land for the purposes of registration, interest of the community land owners or the target group is mentioned clearly in this policy.

The main principle of registration of land rights is to facilitate security over land ownership and transfer of rights. In addition, land registration is made to find whether there are the rights of third parties. The principal ideas in the registration system is to record the rights to land, and then replace the proof of ownership of land titling. The principle of land registration must reflect a rigor regarding the ownership of the land and the rights of third parties that affect it. The principle is the registration guarantees rights status, guarantees of the accuracy of a list, even should provide compensation to those who suffered losses. ${ }^{8}$

\footnotetext{
7 Soerjono Soekanto 1984 Pengantar Penelitian Hukum UI Press Jakarta p. 6.

${ }^{8}$ Adrian Sutedi 2014 Sertifikat Hak Atas Tanah Cet. 3 Sinar Grafika Jakarta p. 59.
} 
Implementation of a complete systematic acceleration of land registration in Article 3, paragraph (4) of Regulation Agrarian minister and Spatial Planning / Head of National Land Agency of the Republic of Indonesia Number 12 Of 2017 on the Acceleration of Complete Systematic Land Registration stated as follows:

- Planning and preparation.

- The stipulation Complete Systematic land registration activities.

- The formation and establishment of the Adjudication Committee Complete Systematic land registration.

- Extension.

- The data collection of physical and juridical plot.

- Edaphology.

- Announcement of physical data and juridical data plots as well as verification of rights.

- Issuance of the decision to grant or recognition of land rights.

- Bookkeeping and issuance of land certificates.

- The delivery of land certificates.

Subang District Land Office is the official sanctioning body of land especially regarding complete systematic land registration in the jurisdiction of the district of Subang implement the registration program of soil Full systematically with the issuance of the decision the district land office head corm number 03 / KEP-2:32:13 / I / 2018 on the determination of the location of the expeditious implementation of Complete Systematic Land Registration in 2018 the county Earring. ${ }^{9}$

Here's a list of locations Complete Systematic Land Registration (PTSL) 2018 in Subang district. Location, target and juridical measurements may change if there is a revision in SK PTSL Location Determination. To see more details please click on a row in the table below:

\begin{tabular}{|c|c|c|c|c|}
\hline No. & Village / Sub & Sub-District & Target field & Information \\
\hline \multicolumn{5}{|c|}{ Package I } \\
\hline 1 & Tanjungrasa kidul & Patokbeusi & 2,600 & \multirow{4}{*}{ KJSKB } \\
\hline 2 & Tanjungrasa & Patokbeusi & 2,600 & \\
\hline 3 & Ciberes & Patokbeusi & 3,500 & \\
\hline 4 & Gempolsari (partially) & Patokbeusi & 1,300 & \\
\hline \multicolumn{4}{|c|}{ Total } & 10,000 \\
\hline \multicolumn{5}{|c|}{ Package II } \\
\hline 5 & Gempol Sari (Most) & Patokbeusi & 1,600 & \multirow{4}{*}{ KJSKB } \\
\hline 6 & Ciasemhilir & Ciasem & 3,600 & \\
\hline 7 & Pinangsari & Ciasem & 2,600 & \\
\hline 8 & Rancabogo & Ciasem & 2,200 & \\
\hline \multicolumn{4}{|c|}{ Total } & 10,000 \\
\hline \multicolumn{5}{|c|}{ Package III } \\
\hline 9 & Rancabogo & Patokbeusi & 4,200 & KJSKB \\
\hline
\end{tabular}

${ }^{9}$ Decision of the district land office head corm number 03 / KEP-2:32:13 / I / 2018 on the determination of the location of the expeditious implementation of complete systematic land registration Program in 2018 the Subang District. 
Volume 5 Issue 4, December 2018

\begin{tabular}{|c|c|c|c|c|}
\hline 10 & Rancaasih & Patokbeusi & 2,700 & \\
\hline 11 & Rancajaya & Patokbeusi & 3,100 & \\
\hline \multicolumn{4}{|c|}{ Total } & 10,000 \\
\hline \multicolumn{4}{|c|}{ Total KJSKB } & 30,000 \\
\hline 12 & Tambakjati & Patokbeusi & 3,900 & \multirow{6}{*}{ ASN } \\
\hline 13 & Sukamandijaya & Ciasem & 5,500 & \\
\hline 14 & Rancamulya & Patokbeusi & 3,500 & \\
\hline 15 & Jatibaru & Ciasem & 4,300 & \\
\hline \multirow[t]{2}{*}{16} & \multirow{2}{*}{ Blanakan } & \multirow{2}{*}{ Blanakan } & 2,800 & \\
\hline & & & $150 *)$ & \\
\hline \multicolumn{4}{|c|}{ Total ASN } & 20.150 \\
\hline \multicolumn{4}{|c|}{ Total KJSKB + ASN } & 50150 \\
\hline
\end{tabular}

*) Note: Intersectoral as Complete Systematic land registration sites fiscal of 2018.

That in the framework of the implementation of priority programs to expedite the implementation of land registration by the government, document preparation needs to be done tenure / ownership of land, infrastructure necessary for communities to land owned can be registered.

That in order to unify the financing preparation complete systematic land registration by the government and free up funding for the community, we need to unify Complete Systematic land registration fees and funding sources setting complete systematic land registration cannot be accommodated in the state government budget.

To be the realization of complete systematic land registration program, the minister ordered the regent / mayor to perform the following steps: ${ }^{10}$

- Budgeted complete systematic land registration fees that are not accommodated in the state government budget and local government budget in accordance with the capabilities of each region.

- Giving the reduction and / or relief or tax exemption fees for acquisition of land and buildings (BPHTB) for beneficiaries certificate in systematic land registration.

- Socializing Complete Systematic land registration requirement to the entire community.

- Regional inspectorate ordered to coordinate with the relevant law enforcement authorities Complete Systematic land registration, in accordance with Article 385 of Act No. 23 of 2014 on Regional Government.

Article 385 of Law number 23 of 2014 on Regional Government stated as follows:

- Communities can submit complaints of alleged irregularities committed by civilian officials in the country to local agencies to the internal supervisory apparatus of government and / or law enforcement.

- The government's internal control official shall check the alleged irregularities complained of by the public referred to in paragraph (1).

\footnotetext{
${ }^{10}$ The joint decision of agrarian and spatial planning minister / head of the national land agency the interior minister minister of villages development of lagging regions and transmigration listed in numbers: 25 / SKB / V / 2017 number: 590-3167A 2017 number: 342017 on financing the preparation of a complete systematic land registration program.
} 
- Law enforcement officers conducted an examination of the complaints submitted by the public as meant in paragraph (1), after prior coordination with the internal regulatory authorities nongovernment or government agency in charge of supervision.

- If based on the results referred to in paragraph (3) there is evidence of irregularities of an administrative nature, the process continued by the internal watchdog of government officials.

- If based on the results referred to in paragraph (3) there is evidence of criminal deviations, further proceedings handed over to law enforcement officials in accordance with the provisions of Regulations."

The joint decision of agrarian and spatial planning minister / head of the national land agency, the interior minister, minister of villages, development of lagging regions and transmigration listed in numbers: 25 / SKB / V / 2017, number: 590-3167A 2017, number: 342017 on financing the preparation of a complete systematic land registration on the magnitude of the costs required to prepare for the implementation referred to is divided into: ${ }^{11}$

- Category I (provinces of Papua, West Papua province, Maluku, North Maluku province, and the province of East Nusa Tenggara) Rp. 450.000,00.

- Category II (the province of Riau Islands, Bangka Belitung province, Central Celebes, North Celebes, Southeast Celebes, East Nusa Tenggara) Rp. 350.000,00.

- Category III (in Gorontalo, West Celebes province, the province of South Celebes province of Central Kalimantan, West Kalimantan province, the Sumatra province of North Sumatra, Aceh province, the province of West Sumatra, East Kalimantan province) Rp. 250,000.00.

- Category IV (province of Riau, Jambi province, South Sumatra, Lampung province, the province of Bengkulu, South Kalimantan) amounting to Rp. 200,000.00.

- Category V (Java and Bali) Rp. 150,000.00.

Financing as in the seventh dictum does not include the cost of a deed, fees for acquisition of land and buildings data (BPHTB) and income tax (VAT). In this case the cost of the preparation of a systematic land registration is not budgeted in the local government budget (APBD) as described above. The interior minister ordered the regent / mayor to make the regulation of regent / mayor that the fee charged to the community.

Activity of Complete Systematic land registration very demanding guarantees of legal certainty. One of the important issues related to the rule of law is the principle of publicity has differences in regulation between government regulation with ministerial regulations. To fulfill the principle of publicity in the proof of ownership of land then executed announcements physical data and juridical that for 14 (fourteen) calendar days (Article 24 of the Regulation of Agricultural and Spatial / Head of National Land Agency Number 6 of 2018).

In practice though land registration has been carried out in Subang district, as well as the presence of land registration systematically complete there are still many obstacles, both the resistance of the land office or from the applicant itself, the obstacles the administration did not complete his file to register the land, the land is registered unpaid taxes and when the registration process takes place, the cost of land registration which is quite expensive, and technically the procedure is burdensome and

${ }^{11}$ Ibid. 
time consuming as well as their levies from unscrupulous party land office that deviate procedure of registration of land for the benefit of the applicant by various modes practice,so that issues concerning the land still disputes over land rights in society that even to the lawsuits to court, resulting in weak implementation of the Complete Systematic Land Registration in Subang and people are still many who do not understand how systematic land registration process complete when the public had the opportunity over the land through a legal guarantee systematic land registration process complete.resulting in weak implementation of the Complete Systematic Land Registration in Subang and people are still many who do not understand how to process a complete systematic land registration when people have the opportunity of legal guarantees over the land through systematic land registration process is complete.resulting in weak implementation of the Complete Systematic Land Registration in Subang and people are still many who do not understand how to process a complete systematic land registration when people have the opportunity of legal guarantees over the land through systematic land registration process is complete.

2.2. Constraints and solutions implementation of Complete systematic land registration program based on Government Regulation No. 24 of 1997 on Land Registration in Subang district.

\subsubsection{Announcements Physical Data and Data Juridical}

Systematic Land Registration activities are very demanding their full legal guarantee. One of the important issues related to the rule of law is the principle of publicity that has differences in regulation between government regulation with ministerial regulations. To fulfill the principle of publicity in the proof of ownership of land then executed announcements physical data and juridical that for 14 (fourteen) calendar days (Article 24 of Regulation ATR / Ka. BPN No. 6 of 2018). This provision differs from Article 26 of Government Regulation No. 24 of 1997 on Land Registration, which requires 30 days and Article 63 PMNA / Ka. BPN No. 3 Of 1997 on the Implementation of Government Regulation No. 24 of 1997 on Land Registration. The principle of publicity of different settings provide space potential disputes in the future, because in principle a lower regulations may not contradict higher laws. ${ }^{12}$

According to the author, the period of announcement of physical data and juridical still the same 14 calendar days under Article 24 measures the acceleration of the completion of Complete Systematic Land Registration only be accommodated in Chapter V of its own, in substance no change with Candy ATR / Ka. BPN No. 12 of 2017. Likewise, the output of Complete Systematic Land Registration set too vague only one paragraph in Article 38 paragraph (3) declare the results of the activities of Complete Systematic Land Registration also conveyed to Accelerate Team One Policy Map Policy to strengthen the data base One Map,

The author argues that the arrangement of contention between regulation ATR / Ka. BPN No. 6 of 2018 by Government Regulation No. 24 of 1997 regarding

12 Soeprapto 2010 Ilmu Perundang- Undangan: Jenis Fungsi Dan Materi Muatan Kanisius Yogyakarta p. 41. 
the timing of the announcement of physical data and juridical. This provision when viewed from the principles of the legislation can be described as follows:

- The principle of lex superior derogat legi inferiorwhich means higher laws override is low (the principle of hierarchy), then used Government Regulation 24 of 1997 because of government regulation is higher in rank than the regulation, since the provisions of Regulation degree lower can not change or override government regulation more high degree, even regulation has no legal force and are not binding if it is contrary to government regulation.

- The principle of lex specialis namely the principle of a special legal rule out the general law, also can not be applied in the use of this principle because the provisions of lex should be equal with the provisions of the lex generalis, such as Law with the Law, Government Regulation with government regulations, and so on ,

- The principle of Lex posterior derogat legi Priori, This principle also to rules equivalent, most new regulations paralyze the old regulation.

The next issue, how the binding force of RegulationMinister ATR / Ka. BPN No. 6 of 2018. Referring to Article 8 (2) of the ActNo. 12 of 2011 states:

"Laws and regulations as referred to in paragraph (1) recognized and have binding legal force throughout ordered by legislation that is higher or formed under the authority of".

in provisionThere are two requirements for a ministerial regulation has binding force as the legislation, which was ordered by the legislation that is higher or established pursuant to the authority. When referring to Article 19 of the Basic Agrarian Law, activities of Complete Systematic Land Registration is an order of Article 19 of the Basic Agrarian Law as a legal source ministerial regulations. This means that the lower regulation must not contradict higher laws.

According to Article 19 of Act No. 5 of 1960 on Basic Regulation of Agrarian inside explains that: "In order to ensure legal certainty by the Government held land registration throughout the territory of the Republic of Indonesia in accordance with the provisions stipulated in Government Regulation. The registration includes:

- Measurement, mapping and soil bookkeeping.

- Registration of rights to land and transfer of these rights.

- Award letters proof of rights, which serves as a strong evidentiary tool."

\subsubsection{Applying the principle Kontradiktur difficult Delimitation}

An activity in the placement of parcels of land boundary agreement between the parties with an interest in the land registry is called the principle of Contradictoire Delimitatie. Kontradiktur delimitation is a norm that is used in the Land Registry by requiring holders of land rights to pay attention to the placement, establishment, and maintenance of boundary by agreement and approval of the parties concerned, which in this case is the owner of the land adjacent to the land he owned. If the land owners bordering not obtain an agreement with the actual position of a boundary despite the application of mediation, then setting boundaries with pengangadilan decision (Articles 17, 18, Application of the principle of Kontradiktur Delimitation work properly if the parties interest is present and gives consent in determining the boundary 
markers. But the reality is different, application of the principle of delimitation kontradiktur experiencing difficulties in the field, both in the implementation of land registration routine as usual and in full Systematic Land Registration program. Some of the factors that led to the principle kontradiktur difficulties delimitation can not be implemented with both of them:

- First, land-rights holders do not maintain a good ground plane boundary which has become a duty which causes overlapping boundaries of plots of land, for no clear plot or limits have been fitted with the pin missing, lack of public awareness to maintain the boundary markers.

- Second, the parties are not present at the time of the delimitation of the land, because of busy landowners and landowners or difficult to find due to absentee land ownership.

- Third, their land boundary disputes, family disputes and disputes or neighbor who has entered the realm of the courts. These problems have become an obstacle to the measurement process.

Socialization in the form of outreach to the community about the importance of the placement, the establishment and maintenance of the land boundary in the process of measurement is the obligation of the land owner, not the authority of officers to measure. The authority officers measurement is to measure the boundary markers have been installed by rights holders and owners of neighboring land is not to put up a sign and liability limits landowners to preserve land boundaries such as boundary markers not installed and owned by the National Land Agency. Similarly, the meaning of the presence and agreement on delimitation of the plot. $^{13}$

\subsubsection{Proof Rights}

Proof rights in the implementation of Complete Systematic Land Registration set out in Article 22 Regulation of the Minister / Ka. BPN No. 6 of 2018. The related issue written statement about the ownership and / or physical control plot in good faith in terms of land ownership records are incomplete or nonexistent, ${ }^{14}$

Article 22 requires the written statement about the physical control plot and in good faith. Affidavit physical custody of the plot must be witnessed by at least two (2) witnesses from the local neighborhood who do not have family ties and can be responsible for both civil and criminal. If in the future there is an element of untruth in a statement, not the responsibility of the Adjudication Committee for Complete Systematic Land Registration. This provision can be interpreted as follows: ${ }^{15}$

- Physical custody of the plot in question is 20 (twenty) years or more in a row can not be less than 20 years and or diselinggi by intervals eg new mastery to 10 years for certain events switch to the other party, then even

13 Ratmono 2007 "Pelibatan masyarakat dan stakeholder terkait dalam percepatan pelaksanaan Pendaftaran Tanah Sistematis Lengkap (PTSL)" Prosiding seminar nasional percepatan pendaftaran tanah di indonesia: Tantangan pelaksanaan PTSL dan respon solusinya Sekolah Tinggi Pertanahan Nasional (STPN) Yogyakarta p. 61.

${ }^{14}$ See Article 22 Regulation of the Minister / Ka. BPN No. 6 of 2018.

${ }^{15}$ Santoso 2010 Pendaftaran Dan Peralihan Hak Atas Tanah Kencana Jakarta p. 45. 
want 20 years back to the mastery of the original, as well as land tenure digangu not contested by the other party in accordance with Article 24 paragraph (2) of Government Regulation No. 24 of 1997.

- Affidavit physical custody of the plot must be witnessed by at least two (2) witnesses. This provision has the potential existence of forgery revelation should be strengthened testimony trustworthy person, for example, witnessed by two witnesses and diketahuioleh RT, RW, and rural / urban. The existence of the legal consequences if found to falsify the contents and signing an affidavit that is willing to be charged upfront in criminal and civil judges for giving false information.

- If there is an element of untruth affidavit is not the responsibility of the Adjudication Committee for Complete Systematic Land Registration. This is a form of self-protection from the law of the Adjudication Committee for Complete Systematic Land Registration and this can be justified because of the evidentiary aspects mempuyai not right judicial authority of the truth of a statement, just right to formal testing on the terms adminsitasi. For example, check the affidavit signed by the parties, the truth about the fit between the person signing is not the authority of the Adjudication Committee.

The author argues for minimizing the occurrence of land disputes, should be the role and coordination of rural / urban not be ignored in making a statement of physical custody of the plot as a formal proof of possession of the land in good faith must be recognition and is justified by customary law community or village / sub concerned.

Furthermore, the element of good faith from the fact physically control, use, exploit and preserve land for generations in a certain time and / or gain by not violate the provisions of the legislation. Good faith is evidenced by the statement of the applicant / participant Complete Systematic Adjudication Land Registry which states: ${ }^{16}$

- There is no objection from the other party on the land owned or not in a state of dispute; and

- Not included or not an asset of the government, local government, or the State Owned Enterprises / Regional Owned Enterprises, or Forest Area

The author argues, is basically a solution interpreted in good faith with honesty, honesty holders of rights in land acquisition, honest in fulfilling the requairment has been determined. Conditions of good faith is the opposite of bad faith or dishonesty. It is difficult to identify in good faith because has abstract meanings, giving rise to different meanings. In good faith within the meaning of Article 22 honest in physical on the ground and honest in fulfilling the requirements specified. Size has done a good faith made by the Adjudication Committee in the form of calculation-calculation in my heart that the applicant has met the administrative requirements that have been determined.

Aternatif solution to elaborate on the problems of law and implementation by strengthening the legal basis for the implementation of the Complete Systematic Land Registration with government regulation, by revising / change

${ }^{16}$ Ibid. p. 47. 
their Government Regulation No. 24 of 1997 on Land Registration and / or implementation of the Complete Systematic Land Registration separately regulated in Government Regulation, so that the degree of law enforcement Complete Systematic Land Registration higher by regulation. Because of the principle of the legislation can be applied several namely:

- First, the principle of lex specialis that special rules may exclude the general rules and provisions in the common law rules still apply, unless specially adjusted to the special legal regulation. For example, regulations on income tax and BPHTB mempuyai tersediri legal regime, of course, the implementation of Complete Systematic Land Registration the income tax and BPHTB can use when setting principle of Lex Specialist Complete Systematic Land Registration in the form of government regulation.

- Second, the principle of Lex Superior Inferior meaning derogat legi higher laws override is low, it is also related to the existence of legislation when juxtaposed with ministerial regulations legal position will always be a matter of debate. Apbila different settings Complete Systematic Land Registration implementation using government regulation, the regulation can be ruled out.

\section{Closing}

\subsection{Conclusion}

- Implementation of complete systematic land registration program in the Subaang district earring positive influence on the creation of orderly land, particularly against the rule of law and orderly administration of land, which is indicated by the number of parcels of land have been able disertipikatkan in the land registration process. This will have an impact on the decrease in the number of land disputes, because residents have proof of land ownership (certificate) and the presence of land records are complete.

- In carrying out a complete systematic land registration program there are obstacles such as the announcement of data held contradictory physical and juridical between the Government Regulation No. 24 of 1997 on Land Registration with Regulation of the Minister of Agrarian And Spatial / Head of National Land Agency Number 3 Of 1997 on the Implementation of Government Regulation No. 24 of 1997 on Land Registration, and lack of understanding of the community will Complete Systematic land registration program.

\subsection{Suggestion}

- Implementation of complete systematic land registration program to be maximized so that people get a corm district legal certainty and legal protection of land rights.

- Government and in particular the National Land Agency to revise and provide solutions implemented announcement of physical data and juridical data between Government Regulation No. 24 of 1997 on Land Registration with Regulation of the Minister of Agrarian And Spatial / Head of National Land Agency 
Number 3 Of 1997 on the Implementation of Government Regulation No. 24 of 1997 on Land Registration, and a lack of understanding of the program of land registration systematically complete in order not contradictory and can bring legal education to the public on the program implementation of land registration systematically complete so that the program can run well.

\section{Bibliography}

[1] Adrian Sutedi, 2014, Sertifikat Hak Atas Tanah, Cet. 3, Sinar Grafika, Jakarta.

[2] Effendi Perangin, Hukum Agraria Indonesia, CV. Rajawali. Jakarta, 1991.

[3] Elucidation of Article 33 paragraph 3 of the Constitution of the republic of Indonesia Of 1945.

[4] Ratmono 2007, "Pelibatan masyarakat dan stakeholder terkait dalam percepatan pelaksanaan Pendaftaran Tanah Sistematis Lengkap (PTSL)", Prosiding seminar nasional percepatan pendaftaran tanah di indonesia: Tantangan pelaksanaan PTSL dan respon solusinya, Sekolah Tinggi Pertanahan Nasional (STPN), Yogyakarta.

[5] Santoso, 2010, Pendaftaran Dan Peralihan Hak Atas Tanah, Kencana, Jakarta.

[6] Soeprapto, 2010, IImu Perundang- Undangan: Jenis, Fungsi, Dan Materi Muatan, Kanisius, Yogyakarta.

[7] Soerjono Soekanto, 1984, Pengantar Penelitian Hukum, UI Press, Jakarta.

[8] Article 22 Regulation of the Minister / Ka. BPN No. 6 of 2018.

[9] Preamble Indonesian Government Regulation No. 24 of 1997 on Land Registration.

[10] Decision of the district land office head corm number 03 / KEP-2:32:13 / I / 2018 on the determination of the location of the expeditious implementation of complete systematic land registration Program in 2018 the Subang District.

[11] The joint decision of agrarian and spatial planning minister / head of the national land agency, the interior minister, minister of villages, development of lagging regions and transmigration listed in numbers: 25 / SKB / V / 2017, number: 5903167A 2017, number: 342017 on financing the preparation of a complete systematic land registration program. 